\title{
Hubungan pH, Eh, dan EC dengan Produksi Kelapa Rakyat pada Tempat Tumbuh yang Berbeda
}

\author{
Andrias Izaac Latupapua \\ Program Studi Ilmu Tanah, Jurusan Budidaya Pertanian, \\ Fakultas Pertanian Universitas Pattimura \\ Jl. Ir. M. Putuhena, Kampus Poka, Ambon 97233 \\ e-mail : andriaslatupapua@gmail.com
}

\begin{abstract}
ABSTRAK
Tiga sifat kimia tanah yang berpengaruh terhadap produksi kelapa rakyat (Cocos nucifera, L.) adalah pH, Eh, dan EC. Nilai masing-masing parameter biasanya berbeda antara tanah di pesisir pantai dengan di gunung. Penelitian ini bertujuan untuk mengetahui hubungan $\mathrm{pH}$, Eh, EC dengan produksi kelapa rakyat yang tumbuh di pesisir pantai dan di gunung. Survei dilakukan dengan mengambil contoh tanah pada kedalaman $40 \mathrm{~cm}$ di sekitar pohon kelapa dan pada tempat yang sama dilakukan pengamatan jumlah buah per pohon untuk mengetahui produksi. Hasil penelitian menunjukkan bahwa $\mathrm{pH}$, Eh dan EC berpengaruh nyata terhadap produksi kelapa di pesisir pantai, sedangkan $\mathrm{pH}$ berpengaruh nyata terhadap produksi di gunung. Produksi di gunung mencapai $80.4 \mathrm{~kg} /$ pohon sedangkan produksi di pesisir pantai $72.4 \mathrm{~kg} /$ pohon.
\end{abstract}

Kata Kunci : kelapa, pH, Eh, Ec.

\section{Relationship between pH, Eh, and EC with Coconut Production at Different Growing Location}

\begin{abstract}
Three soil chemical properties including $\mathrm{pH}$, Eh, and EC can affect coconut (Cocos nucifera, L.) production. The value of each parameter is usually different from coastal and mountainous soils. This study aims to determine the relationship between $\mathrm{pH}, \mathrm{Eh}, \mathrm{EC}$ and the coconut production of the coastal and mountainous areas. The study method was survey, soil samples were taken at $40 \mathrm{~cm}$ depth around the coconut trees, and the number of coconut fruit per tree was observed to determine coconut production. The results showed that the $\mathrm{pH}$, Eh and EC significantly affect the production of the coastal coconuts, while $\mathrm{pH}$ significantly affects the production of the mountainous coconuts. The production of the mountainous coconuts reaches $80.4 \mathrm{~kg} /$ tree, while the coastal coconuts is $72.4 \mathrm{~kg} /$ tree.
\end{abstract}

Keywords : Coconuts, pH, Eh, Ec.

\section{PENDAHULUAN}

Tanaman kelapa (Cocos nucifera, L.) umumnya diusahakan oleh petani di Maluku. Tanaman ini dijumpai di seluruh desa/negeri baik sebagai tanaman yang ditanam maupun yang tumbuh secara alami. Oleh karena itu maka tanaman kelapa di Maluku umumnya merupakan kelapa rakyat yang dikonsumsi dan dijual untuk memenuhi kebutuhan keluarga.

Data produksi kelapa nasional tercatat 2.87 juta ton setara kopra, sedangkan di Maluku tergolong masih rendah yaitu 102624 ton. ${ }^{[1]}$ Dalam hal ini produksi kelapa di Kota Ambon 800 ton ${ }^{[2]}$ sedangkan di Kabupaten Maluku Tengah 3184 ton ${ }^{[3]}$. Rendahnya produksi kelapa rakyat ini berkaitan dengan 
faktor-faktor pembatas pertumbuhan tanaman kelapa. Beberapa faktor pembatas pertumbuhan dan produksi tanama kelapa adalah ketersediaan air, ketersediaan oksigen, media perakaran, retensi hara, hara tersedia, toksisitas, sodisitas, bahaya, bahaya erosi, bahaya banjir dan genangan, serta kondisi batuan permukaan ${ }^{[4]}$. Karakteristik dan kualitas lahan yang membatasi pertumbuhan kelapa erat hubungannya dengan sifat-sifat kimia tanah yaitu retensi hara yang diwakili oleh $\mathrm{pH}\left(\mathrm{H}_{2} \mathrm{O}\right)$, ketersediaan oksigen di sekitar perakaran yang berkaitan dengan potensi reduksi oksidasi (Eh) dan toksisitas garam terlarut yang diwakili oleh daya hantar listrik atau electrical conductivity (EC).

Berdasarkan kriteria kesesuaian lahan untuk tanaman kelapa (Cocos nucifera, L.) $\mathrm{pH}$ yang sesuai berkisar antara 4.8 sampai 7.5 dengan drainase tanah agak terhambat sampai agak cepat dan salinitas $<20 \mathrm{dS} / \mathrm{m}^{[4]}$. Kisaran $\mathrm{pH}$ tanah yang cukup luas dari masam sampai basa akan menentukan ketersediaan unsur hara esensial terutama $\mathrm{P}$. Pada tanah dengan $\mathrm{pH}$ masam akan terjadi kesetimbangan kimia $\mathrm{P}$ dengan $\mathrm{Al}$ sedangkan pada $\mathrm{pH}$ basa dengan $\mathrm{Ca}$ dan $\mathrm{Mg}^{[5]}$ dan reaksi ini membentuk senyawa sukar larut sehingga $\mathrm{P}$ tidak tersedia untuk diserap tanaman ${ }^{[6,7,8]}$.

Hubungan $\mathrm{pH}$ dengan produksi kelapa secara tidak langsung melalui peran $\mathrm{pH}$ dalam ketersediaan unsur hara esensial terutama $\mathrm{P}$ dalam bentuk ortofosfat $\mathrm{H}_{2} \mathrm{PO}_{4}{ }^{-}$dan $\mathrm{HPO}_{4}{ }^{2-}$. Penurunan 1 unit $\mathrm{pH}$ akan meningkatkan nisbah $\mathrm{H}_{2} \mathrm{PO}_{4}{ }^{-} / \mathrm{HPO}_{4}{ }^{2-}$ sepuluh kali, sebaliknya peningkatan 1 unit $\mathrm{pH}$ akan menurunkan rasio sepuluh kali ${ }^{[5]}$. Kisaran $\mathrm{pH}$ untuk ketersediaan $\mathrm{P}$ bagi tanaman antara $\mathrm{pH}$ 6 sampai 7 untuk sebagian besar tanah pertanian ${ }^{[7,8]}$. Fosfat yang diserap tanaman memiliki fungsi regulasi fotosintesis dan karbohidrat [9]. Oleh sebab itu $\mathrm{pH}$ tanah berpengaruh terhadap produksi kelapa. Produksi akan menurun jika $\mathrm{pH}$ tanah tidak sesuai untuk pertumbuhan. Hasil penelitian pada tanaman kelapa sawit menunjukkan bahwa berubahnya kedalaman pirit disertai penurunan $\mathrm{pH}$ mengakibatkan penurunan produksi sebesar 26 persen ${ }^{[10]}$.

Ketersediaan oksigen di sekitar perakaran tanaman dipengaruhi kadar air tanah. Tanah yang sering dipengaruhi genangan atau permukaan air tanah tinggi akan mempunyai kadar oksigen rendah sehingga tanah berada dalam kondisi reduktif. Sebaliknya tanah kering akan banyak mengandung oksigen sehingga berada dalam keadaan oksidatif. Nilai potensial redoks (Eh) tanah mengalami penurunan dan kadar $\mathrm{P}$ meningkat dengan bertambahnya tinggi genangan ${ }^{[11]}$. Oleh sebab itu tanah-tanah di pesisir pantai umumnya lebih bersifat reduktif sedangkan tanah-tanah di pegunungan bersifat oksidatif.

Nilai daya hantar listrik suatu tanah menunjukkan konsentrasi ion-ion terlarut dalam larutan tanah. Ion-ion hara esensial dari larutan tanah masuk ke dalam akar tanaman melalui lintasan apoplast dan simplas ${ }^{[9]}$. Hasil penelitian pengaruh EC terhadap pertumbuhan sawi (Brassica juncea, L.) menunjukkan bahwa naiknya nilai EC larutan akan meningkatkan pertumbuhan tanaman sawi ${ }^{[12]}$. Oleh sebab itu maka penyerapan hara dan produksi tanaman kelapa juga dapat dipengaruhi oleh nilai EC tanah.

Penelitian ini dilaksanakan untuk mengetahui hubungan $\mathrm{pH}$, Eh dan EC tanah dengan produksi kelapa rakyat pada pesisir pantai dan pegunungan.

\section{BAHAN DAN METODE}

Penelitian dilaksanakan pada lahan kelapa rakyat yang mewakili pesisir pantai dan pegunungan. Pengamatan sifat kimia tanah dan produksi kelapa pesisir pantai berlokasi di Negeri Hunuth, Kecamatan Teluk Ambon, Kota Ambon sedangkan pegunungan berlokasi di Desa Hitulama, Kecamatan Leihitu, Kabupaten Maluku Tengah (Gambar 1) 


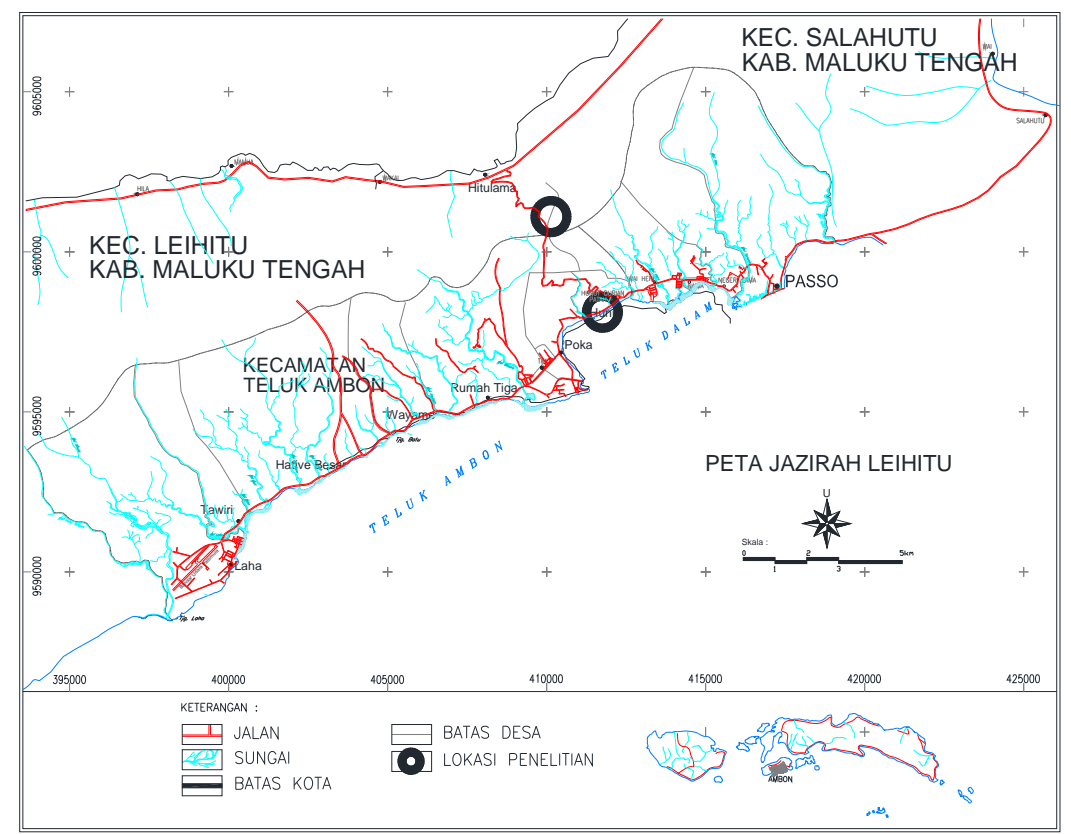

Gambar 1. Peta Lokasi Penelitian di Jazirah Leihitu

Daerah pesisir bertopografi datar dengan kelerengan 0-3 \% dengan geologi Qa yang merupakan kerakal, kerikil, lanau, pasir, lempung dan sisa tumbuhan. Sedangkan lokasi pegunungan bertopografi bergelombangberbukit terletak pada geologi Tpav yaitu Batuan Gunung Api Ambon dengan komposisi andesit, dasit, breksi, dan tuf. Tipe iklim di lokasi penelitian adalah tipe iklim B berdasarkan klasifikasi Schmidt dan Ferguson [13].

Penelitian ini menggunakan metode survei dengan menentukan 15 titik pengamatan di sepanjang pesisir pantai dan mengambil contoh tanah secara komposit pada kedalaman 0-40 cm di sekitar pohon kelapa. Pada lokasi yang sama dilakukan pengamatan produksi tandan per pohon. Hal serupa juga dilakukan pada lokasi pegunungan dengan 15 titik pengamatan. Contoh tanah dianalisis di Laboratorium Analisis Tanah, Air dan Tanaman Fakultas Pertanian Universitas Pattimura. Parameter kimia tanah yang dianalisis adalah $\mathrm{pH}\left(\mathrm{H}_{2} \mathrm{O}\right.$ 1:2.5), potensial redoks $\mathrm{Eh}(\mathrm{mV})$, dan daya hantar listrik EC (dS/m).

Untuk mengetahui hubungan antara sifat kimia tanah dengan produksi kelapa dilakukan analisis regresi berganda dengan Backward Elimination. Uji asumsi klasik dilakukan terhadap data penelitian yaitu Uji Normalitas, Multikolinearitas, Heteroskedastisitas, dan Linieritas. Untuk mengetahui adakah perbedaan mean atau rerata yang bermakna antara produksi kelapa pantai dengan pegunungan dilakukan Uji Komparatif (Independen $\mathrm{T}$ test).

\section{HASIL DAN PEMBAHASAN}

\section{pH, Eh, dan EC tanah pesisir}

Hasil analisis $\mathrm{pH}$, potensial redoks (Eh), dan daya hantar listrik (EC) tanah pesisir disajikan pada Tabel 1 . 
Latupapua, 2020. Hubungan pH, Eh ....

Tabel 1. Nilai karakteristik kimia tanah pesisir

\begin{tabular}{llrrrr}
\hline Parameter & $\mathrm{N}$ & Minimum & Maximum & \multicolumn{1}{c}{ Rataan } & Simpangan Baku \\
\hline $\mathrm{pH}\left(\mathrm{H}_{2} \mathrm{O} 1: 2.5\right)$ & 15 & 5.90 & 6.70 & 6.3133 & 0.21668 \\
$\mathrm{Eh}(\mathrm{mV})$ & 15 & 200.00 & 290.00 & 242.2000 & 29.77823 \\
$\mathrm{EC}(\mathrm{dS} / \mathrm{m})$ & 15 & 0.16 & 0.19 & 0.1853 & 0.00834 \\
Valid N (Listwise) & 15 & & & & \\
\hline
\end{tabular}

Kriteria kesesuaian lahan untuk kelapa (Cocos nucifera, L.) menunjukkan bahwa nilai pH tanah 5.2 sampai 7.5 merupakan nilai yang sangat sesuai (S1) ${ }^{[4]}$. Hasil analisis tanah di laboratorium menunjukkan bahwa rataan nilai $\mathrm{pH}$ tanah pesisir adalah sebesar 6.3 atau agak masam dan masuk kisaran sangat sesuai untuk tanaman kelapa.

Hasil analisis potensial redoks (Eh) tanah pesisir menunjukkan nilai rataan Eh $242.2 \mathrm{mV}$. Nilai ini berada pada kisaran suboksik $118 \mathrm{mV}$ sampai $413 \mathrm{mV}{ }^{[6]}$. Hal ini disebabkan tanah sering digenangi oleh air laut dan permukaan air tanah yang dangkal. Kondisi oksidasi dan reduksi berlangsung secara bergantian mengikuti volume pori tanah yang terisi air dan udara. Kondisi tanah yang secara periodik mengalami penggenangan akan berpengaruh terhadap ketersediaan hara esensial. Semakin tinggi genangan semakin menurun tingkat kelarutan $\mathrm{Fe}$ dan $\mathrm{Al}$, yang disertai dengan peningkatan ketersediaan $\mathrm{P}$ dalam larutan tanah [11]. Dalam kondisi suboksik terjadi reduksi $\mathrm{NO}_{3}{ }^{-}$dan $\mathrm{NO}_{2}{ }^{-}$diikuti oleh reduksi $\mathrm{MnO}_{2}$. Kehilangan ini tidak terlalu besar karena nilai Eh masih berada pada pertengahan kondisi suboksik sehingga $\mathrm{N}$ dan Mn masih tersedia.

Hasil analisis daya hantar listrik (EC) tanah pesisir menunjukkan nilai rataan 0.18 $\mathrm{dS} / \mathrm{m}$. Nilai EC ini sangat sesuai untuk tanaman kelapa karena $<12 \mathrm{dS} / \mathrm{m}$ sebagai nilai batas kelas kesesuaian S1 ${ }^{[4]}$. Dengan rendahnya nilai EC maka kadar garam terlarut juga rendah sehingga tidak menimbulkan efek salinitas.

\section{Hubungan pH, Eh, EC dengan Produksi kelapa di Pesisir}

Pada tanah pesisir, produksi kelapa dipengaruhi secara nyata oleh $\mathrm{pH}$, Eh, dan EC tanah menurut persamaan regresi berganda :

$\mathrm{Y}=190.985-11.606 \mathrm{pH}-0.364 \mathrm{Eh}+$ $231.298 \mathrm{EC} ; \mathrm{R}=0.985$

yang telah melalui serangkaian uji statistika seleksi variabel metode Langkah Mundur (Backward) dan uji asumsi klasik (Tabel 2).

Persamaan regresi berganda menunjukkan bahwa peningkatan nilai $\mathrm{pH}$ tanah menurunkan produksi kelapa pada tanah di pesisir pantai. Hal ini disebabkan karena pada $\mathrm{pH}$ di atas 6.3 maka hara $\mathrm{P}$ akan terfiksasi oleh $\mathrm{Ca}$ dan $\mathrm{Mg}$ tanah menjadi bentuk-bentuk senyawa yang sukar larut dan $\mathrm{P}$ menjadi kurang tersedia bagi tanaman ${ }^{[5,6]}$. Beberapa senyawa $\mathrm{P}$ yang sukar larut pada $\mathrm{pH}$ basa antara lain brushite, monetite, oktakalsium fosfat, dan apatite ${ }^{[7,8]}$. Fungsi fosfat dalam tanaman antara lain dalam regulasi dan metabolisme karbohidrat. ${ }^{[9]}$ Oleh sebab itu maka peningkatan nilai $\mathrm{pH}$ akan menurunkan produksi kelapa pada tanah pesisir.

Peningkatan potensial redoks tanah (Eh) menurunkan produksi pada tanah pesisir. Oleh karena tanah pesisir berada pada kondisi suboksik, maka peningkatan nilai Eh menuju kondisi normal (oksik) berarti terjadi perbaikan kondisi drainase tanah. Dalam kondisi drainase agak cepat atau cepat maka tanah kurang sesuai bahkan menjadi tidak sesuai untuk pertumbuhan dan produksi kelapa. Dalam kriteria kesesuaian lahan untuk pertumbuhan kelapa yaitu kelas cukup sesuai (S3) dibatasi oleh drainase agak cepat sedangkan kelas tidak sesuai (N) karena drainase cepat ${ }^{[4]}$. Oleh karena kelarutan $\mathrm{P}$ meningkat akibat penggenangan [11], maka pengeringan tanah menjadi kondisi oksidatif akan menurunkan ketersediaan P. Hara P 
sangat penting dalam pertumbuhan dan produksi tanaman, maka peningkatan Eh tanah pesisir akan menurunkan produksi tanaman kelapa.

Salinitas tanah yang dicirikan oleh nilai daya hantar listrik (EC) berpengaruh positif terhadap produksi kelapa di pesisir. Rendahnya nilai EC (Tabel 1) menunjukkan rendahnya garam-garam terlarut dalam tanah $[5,6,7,8]$. Garam-garam terlarut dalam tanah berada dalam bentuk senyawa yang dibutuhkan tanaman. Senyawa-senyawa dimaksud akan terurai dan menghasilkan ionion hara untuk diserap melalui akar. Senyawa yang berperan penting dalam regulasi produksi adalah senyawa fosfat. Senyawa ini banyak tersedia dalam bentuk ion $\mathrm{H}_{2} \mathrm{PO}_{4}^{-}$untuk diserap tanaman pada tanah dengan $\mathrm{pH}$ sekitar $6.5^{[5]}$. Oleh sebab itu peningkatan EC akan meningkatkan produksi kelapa pada tanah pesisir. Meskipun demikian nilai EC tanah tidak boleh melebihi nilai $20 \mathrm{dS} / \mathrm{m}$ karena sudah tidak sesuai untuk tanaman kelapa ${ }^{[4]}$.

Tabel 2. Resume uji statistika regresi produksi dan parameter kimia tanah pesisir

\begin{tabular}{|c|c|c|c|c|}
\hline Uraian & Parameter uji & Nilai & Kaidah & Ket. \\
\hline Anava regresi & F hitung & 117.785 & Sig 0.000 & Nyata bermakna \\
\hline \multicolumn{5}{|l|}{ Koefisien regresi } \\
\hline - Konstanta & thitung & 8.681 & Sig 0.000 & Nyata bermakna \\
\hline$-\quad \mathrm{pH}$ & t hitung & -2.833 & Sig 0.016 & Nyata bermakna \\
\hline - $\quad \mathrm{Eh}$ & t hitung & -16.729 & Sig 0.000 & Nyata bermakna \\
\hline$-\quad$ Ec & t hitung & 2.279 & Sig 0.044 & Nyata bermakna \\
\hline \multicolumn{5}{|l|}{ Kolinearitas } \\
\hline$-\quad \mathrm{pH}$ & Tolerance & 0.397 & $\mathrm{~T}>0.1$ & Tidak ada multikolinearitas \\
\hline Eh & Tolerance & 0.745 & $\mathrm{~T}>0.1$ & Tidak ada multikolinearitas \\
\hline$-\quad \mathrm{Ec}$ & Tolerance & 0.437 & $\mathrm{~T}>0.1$ & Tidak ada multikolinearitas \\
\hline \multicolumn{5}{|l|}{ Linieritas } \\
\hline - $\quad$ Produksi $* \mathrm{pH}$ & F hitung & 0.265 & Sig 0.920 & Terdapat hubungan linier \\
\hline - $\quad$ Produksi $*$ Eh & F hitung & 0.795 & Sig 0.716 & Terdapat hubungan linier \\
\hline - $\quad$ Produksi $*$ EC & F hitung & 0.586 & Sig 0.459 & Terdapat hubungan linier \\
\hline \multicolumn{5}{|c|}{ Heteroskedastisitas } \\
\hline$-\mathrm{pH}$ & t hitung & -0.491 & Sig 0.633 & $\begin{array}{l}\text { Tidak ada } \\
\text { heteroskedastisitas }\end{array}$ \\
\hline - $\quad$ Eh & t hitung & -1.357 & Sig 0.202 & $\begin{array}{l}\text { Tidak ada } \\
\text { heteroskedastisitas }\end{array}$ \\
\hline$-\quad \mathrm{Ec}$ & t hitung & 0.700 & Sig 0.499 & $\begin{array}{l}\text { Tidak ada } \\
\text { heteroskedastisitas }\end{array}$ \\
\hline $\begin{array}{c}\text { Normalitas K-S } \\
\text { Asymp. Sig } \\
\text { (2-tailed) }\end{array}$ & $\begin{array}{l}\text { Unstandardized } \\
\text { Residual }\end{array}$ & 0.175 & Sig 0.2 & $\begin{array}{l}\text { Residual terdistribusi } \\
\text { normal }\end{array}$ \\
\hline
\end{tabular}

Persamaan regresi berganda menunjukkan bahwa peningkatan nilai $\mathrm{pH}$ tanah menurunkan produksi kelapa pada tanah di pesisir pantai. Hal ini disebabkan karena pada $\mathrm{pH}$ di atas 6.3 maka hara $\mathrm{P}$ akan terfiksasi oleh $\mathrm{Ca}$ dan $\mathrm{Mg}$ tanah menjadi bentuk-bentuk senyawa yang sukar larut dan $\mathrm{P}$ menjadi kurang tersedia bagi tanaman ${ }^{[5,6]}$. Beberapa senyawa $\mathrm{P}$ yang sukar larut pada $\mathrm{pH}$ basa antara lain brushite, monetite, oktakalsium fosfat, dan apatite ${ }^{[7,8]}$. Fungsi fosfat dalam tanaman antara lain dalam regulasi dan metabolisme karbohidrat ${ }^{[9]}$. Oleh sebab itu 
maka peningkatan nilai $\mathrm{pH}$ akan menurunkan produksi kelapa pada tanah pesisir.

Peningkatan potensial redoks tanah (Eh) menurunkan produksi pada tanah pesisir. Oleh karena tanah pesisir berada pada kondisi suboksik, maka peningkatan nilai Eh menuju kondisi normal (oksik) berarti terjadi perbaikan kondisi drainase tanah. Dalam kondisi drainase agak cepat atau cepat maka tanah kurang sesuai bahkan menjadi tidak sesuai untuk pertumbuhan dan produksi kelapa. Dalam kriteria kesesuaian lahan untuk pertumbuhan kelapa yaitu kelas cukup sesuai (S3) dibatasi oleh drainase agak cepat sedangkan kelas tidak sesuai (N) karena drainase cepat ${ }^{[4]}$. Oleh karena kelarutan $\mathrm{P}$ meningkat akibat penggenangan ${ }^{[11]}$, maka pengeringan tanah menjadi kondisi oksidatif akan menurunkan ketersediaan P. Hara P sangat penting dalam pertumbuhan dan produksi tanaman, maka peningkatan Eh tanah pesisir akan menurunkan produksi tanaman kelapa.
Salinitas tanah yang dicirikan oleh nilai daya hantar listrik (EC) berpengaruh positif terhadap produksi kelapa di pesisir. Rendahnya nilai EC (Tabel 1) menunjukkan rendahnya garam-garam terlarut dalam tanah [5,6,7,8]. Garam-garam terlarut dalam tanah berada dalam bentuk senyawa yang dibutuhkan tanaman. Senyawa-senyawa dimaksud akan terurai dan menghasilkan ionion hara untuk diserap melalui akar. Senyawa yang berperan penting dalam regulasi produksi adalah senyawa fosfat. Senyawa ini banyak tersedia dalam bentuk ion $\mathrm{H}_{2} \mathrm{PO}_{4}^{-}$untuk diserap tanaman pada tanah dengan $\mathrm{pH}$ sekitar $6.5^{[5]}$. Oleh sebab itu peningkatan EC akan meningkatkan produksi kelapa pada tanah pesisir. Meskipun demikian nilai EC tanah tidak boleh melebihi nilai $20 \mathrm{dS} / \mathrm{m}$ karena sudah tidak sesuai untuk tanaman kelapa ${ }^{[4]}$.

\section{pH, Eh, dan EC tanah pegunungan}

Hasil analisis $\mathrm{pH}$, potensial redoks (Eh), dan daya hantar listrik (EC) tanah pegunungan disajikan pada Tabel 3.

Tabel 3. Nilai karakteristik kimia tanah pegunungan

\begin{tabular}{lcrrrr}
\hline \multicolumn{1}{c}{ Parameter } & N & Minimum & Maximum & Rataan & Simpangan Baku \\
\hline $\mathrm{pH}\left(\mathrm{H}_{2} \mathrm{O} 1: 2.5\right)$ & 15 & 4.50 & 6.20 & 5.41 & 0.51251 \\
$\mathrm{Eh}(\mathrm{mV})$ & 15 & 476.00 & 499.00 & 488.33 & 7.02716 \\
$\mathrm{EC}(\mathrm{dS} / \mathrm{m})$ & 15 & 0.189 & 0.201 & 0.19 & 0.00363 \\
Valid N (Listwise) & 15 & & & & \\
\hline
\end{tabular}

Data pada Tabel 3 menunjukkan bahwa tanah di lokasi pegunungan tergolong masam menurut kriteria penilaian Lembaga Penelitian Tanah tetapi masih sangat sesuai untuk tanaman kelapa ${ }^{[4]}$. Rendahnya nilai $\mathrm{pH}$ tanah pegunungan berhubungan dengan komposisi Batuan Gunung Api Ambon (Tpav) yang mengandung mineral aluminium silikat. Hal ini sesuai hasil analisis mineralogi tanah dengan bahan induk Dasit di Jazirah Leihitu mengandung mineral kuarsa dan haloisit ${ }^{[14]}$. Mineral aluminium silikat dalam tanah terurai dan melepaskan ion $\mathrm{Al}^{[5]}$ dan selanjutnya ion
Al mengalami hidrolisis menghasilkan ion $\mathrm{H}^{+}$ yang mengasamkan tanah ${ }^{[6,7,8]}$.

Nilai rataan potensial redoks tanah menunjukkan bahwa tanah gunung dalam keadaan oksidatif. Hal ini sesuai kriteria redoks tanah yaitu tanah dengan $\mathrm{Eh}>413 \mathrm{mV}$ disebut tanah normal dalam keadaan oksidatif $[6,7]$. Kondisi oksidatif terjadi karena air sulit tergenang pada tanah-tanah dengan topografi berbukit-bergelombang.

Daya hantar listrik (EC) tanah pegunungan sebesar $0.19 \mathrm{dS} / \mathrm{m}$ merupakan nilai salinitas sangat rendah menunjukkan bahwa kadar garam-garam terlarut sangat 
rendah. Hal ini disebabkan adanya pelindian dan pengenceran garam-garam oleh air hujan. Pengaruh pembasahan dan pengenceran sangat jauh menurunkan EC pada tanah sebagai petunjuk bahwa garam-garam mudah digelontor atau dilindi dari dalam tanah ${ }^{[15]}$.

Hubungan pH, Eh, EC dengan Produksi kelapa di Pegunungan

Pada tanah pegunungan, produksi kelapa dipengaruhi secara nyata oleh $\mathrm{pH}$ tanah sedangkan parameter Eh dan EC tidak berpengaruh nyata dan dikeluarkan (removed) dari model. Persamaan regresi sederhana hubungan produksi kelapa dan $\mathrm{pH}$ tanah adalah :

$\mathrm{Y}=28.779+9.541 \mathrm{pH} ; \mathrm{R}=0.916$

yang telah melalui serangkaian uji statistika seleksi variabel metode Langkah Mundur (Backward) dan uji asumsi klasik (Tabel 4).

Tabel 4. Resume uji statistika regresi produksi dan $\mathrm{pH}$ tanah pegunungan

\begin{tabular}{llrll}
\hline Uraian & Parameter uji & Nilai & Kaidah & Keterangan. \\
\hline Anava regresi & F hitung & 67.493 & Sig 0.000 & Nyata bermakna \\
$\begin{array}{l}\text { Koefisien regresi } \\
-\quad \text { Konstanta }\end{array}$ & t hitung & 4.559 & Sig 0.001 & Nyata bermakna \\
$-\quad$ pH & t hitung & 8.215 & Sig 0.000 & Nyata bermakna \\
$\begin{array}{l}\text { Linieritas } \\
\text { Produksi } * \mathrm{pH}\end{array}$ & F hitung & 2.536 & Sig 0.240 & Terdapat hubungan linier \\
$\begin{array}{l}\text { Heteroskedastisitas } \\
\text { - pH }\end{array}$ & t hitung & -0.780 & 0.449 & Tidak ada heteroskedastisitas \\
$\begin{array}{l}\text { Normalitas K-S } \\
\begin{array}{l}\text { Asymp. Sig } \\
(2-t a i l e d)\end{array}\end{array}$ & Unstandardized & 0.181 & Sig 0.2 & Residual terdistribusi normal \\
\hline
\end{tabular}

Produksi kelapa pada tanah pegunungan nyata dipengaruhi oleh $\mathrm{pH}$ tanah. Koefisien korelasi sebesar 0.916 menunjukkan bahwa 83.9 persen kontribusi $\mathrm{pH}$ tehadap produksi kelapa. Rendahnya $\mathrm{pH}$ tanah akan menyebabkan menurunnya ketersediaan hara bagi tanaman yang pada akhirnya akan menurunkan produksi Tandan Buah Segar (TBS) ${ }^{[16]}$. Peran $\mathrm{pH}$ tanah terutama dalam penyediaan hara esensial bagi pertumbuhan tanaman. Hara esensial yang berhubungan dengan fotosintesis dan produksi adalah $\mathrm{P}{ }^{[9]}$. Peningkatan unsur hara $\mathrm{P}$ akan meningkatnya bobot tandan buah segar kelapa. Hal ini dibuktikan dengan peningkatan kadar $\mathrm{P}$ daun dari 0.198 persen menjadi 0.227 persen sejalan dengan naiknya produksi kelapa sawit dari $21.476 \mathrm{~kg}$ menjadi $30.45 \mathrm{~kg}$ per tandan ${ }^{[17]}$. Dengan demikian maka peningkatan $\mathrm{pH}$ tanah akan meningkatkan produksi kelapa di pegunungan.

\section{Perbandingan produksi}

Rataan produksi kelapa di pesisir pantai adalah $72.36 \mathrm{~kg}$ per pohon dengan simpangan baku $10.68 \mathrm{~kg}$ sedangkan di pegunungan 80.4 $\mathrm{kg}$ per pohon dengan simpangan baku $5.34 \mathrm{~kg}$. Hasil uji banding antara rataan produksi menunjukkan bahwa produksi kelapa pegunungan berbeda nyata dengan produksi di pantai. (sig. 2-tailed 0.014). Hal ini disebabkan karena pertumbuhan kelapa di pesisir dibatasi oleh faktor $\mathrm{pH}$, Eh dan EC sedangkan di pegunungan hanya oleh faktor $\mathrm{pH}$.

\section{KESIMPULAN}

Produksi kelapa rakyat di pesisir pantai dipengaruhi nyata oleh $\mathrm{pH}$, Eh, dan EC 
sedangkan di gunung hanya dipengaruhi oleh $\mathrm{pH}$. Parameter $\mathrm{pH}$ dan Eh tanah pesisir pantai berkontribusi terhadap penurunan produksi sebaliknya EC meningkatkan produksi. Parameter $\mathrm{pH}$ tanah gunung berkontribusi meningkatkan produksi. Produksi kelapa di pesisir pantai rata-rata $72.4 \mathrm{~kg} /$ pohon nyata lebih rendah dari produksi di gunung yang mencapai $80.4 \mathrm{~kg} /$ pohon.

\section{DAFTAR PUSTAKA}

[1] Badan Pusat Statistik Provinsi Maluku. 2019. Provinsi Maluku dalam Angka. BPS Provinsi Maluku, Ambon.

[2] Badan Pusat Statistik Kota Ambon. 2020. Kota Ambon dalam Angka. BPS Kota Ambon, Ambon.

[3] Badan Pusat Statistik Kabupaten Maluku Tengah. 2020. Kabupaten Maluku Tengah dalam Angka. BPS Kabupaten Maluku Tengah, Masohi

[4] Ritung, S., K. Nugroho, A. Mulyani, E. Suryani. 2011. Petunjuk Teknis Evaluasi Lahan untuk Komoditas Pertanian. Balai Besar Penelitian dan Pengembangan Sumberdaya Lahan Pertanian. Badan Penelitian dan Pengembangan Pertanian, Kementerian Pertanian, Bogor.

[5] Lindsay, W.L. 1979. Chemical Equilibria in Soils. John Wiley \& Sons Inc. New York.

[6] Kim H. Tan. 1998. Principles of soil chemistry. Marcel Dekker, Inc. New York

[7] Bohn, H.L., B.L. McNeal, G.A O'Çonnor. 2001. Soil Chemistry. John Wiley \& Sons Inc. New York.

[8] Sposito, G. 1989. The Chemistry of Soils. Oxford Univ. Press, Inc. New York.

[9] Marschner, H. 1986. Mineral Nutrition of Higher Plants. Academic Press, Inc. Harcourt Brace Jovanovich Publ. London.
[10] Sutandi, A., B. Nugroho, B. Sejati. 2011. Hubungan Kedalaman Pirit dengan Beberapa Sifat Kimia Tanah dan Produksi Kelapa Sawit (Elais guineensis). J. Tanah Lingk., 13 (1) : 2124

[11] Muhammad Basir Cyio. 2008. Efektivitas bahan organik dan tinggi genangan terhadap perubahan $\mathrm{pH}$, Eh, dan status $\mathrm{Fe}, \mathrm{P}, \mathrm{Al}$ terlarut pada tanah Ultisol. J. Agroland 15 (4) : 257 - 263.

[12] Pratiwi, P.R., M. Subandi, E. Mustari. 2015. Pengaruh Tingkat EC (Electrical Conductivity) terhadap Pertumbuhan Tanaman Sawi (Brassica juncea, L.) pada Sistem Instalasi Aeroponik Vertikal. Jurnal Agro Vol. II (1): 50-55

[13] Schmidt, F. H dan Ferguson, J. H. A. 1951. Rainfall Types Based On Wet and Dry Period Rations for Indonesia With Western New Guinea. Jakarta: Kementrian Perhubungan Meteorologi dan Geofisika.

[14] Latupapua, A.I. 1999. Efek Pupuk K dan Ca terhadap Desorpsi P, Selektivitas Pertukaran Al-K dan Al-Ca, serta Hasil Padi Gogo Pada Inceptisol. Disertasi. Universitas Padjadjaran. Bandung.

[15] Noor, M., A. Maas, T. Notohadikusomo.2008. Pengaruh pengeringan dan pembasahan terhadap sifat kimia tanah sulfat masam Kalimantan. Jurnal Tanah dan Iklim 27 : 33-44

[16] Darlita, R.R., B. Joy, R. Sudirja. 2017. Analisis Beberapa Sifat Kimia Tanah Terhadap Peningkatan Produksi Kelapa Sawit pada Tanah Pasir di Perkebunan Kelapa Sawit Selangkun. Jurnal Agrikultura 28 (1): 15-20.

[17] Marlina, A. Napoleon, D. Budianta. 2018. Perubahan beberapa sifat kimia tanah dan biologi Ultisol dan serapan NPK serta produksi tandan buah segar yang diberi LCPKS. Klorofil XIII - 1 : $37-41$. 